\title{
Application limestone forms and doses for Alfalfa in no-tillage system ${ }^{1}$
}

\author{
Formas de aplicação e doses de calcário para Alfafa cultivada em sistema plantio \\ direto consolidado
}

\author{
Letícia Cristina Bertusso Toffolli², Tangriani Simioni Assmann ${ }^{3 *}$, Alceu Luiz Assmann4, Luís César Cassol ${ }^{3}$, \\ Rodolfo Brandelero Toffolli ${ }^{5}$, Vinícius Nicola ${ }^{6}$ e Jussara Ferrazza ${ }^{7}$
}

\begin{abstract}
Alfalfa (Medicago sativa L.) requires good soil fertility. Brazil is characterized by acidic soils which reduce the potential of the crop. Generally, liming is incorporated into the soil, but in tillage systems it is inadvisable. This study aimed to evaluate the effects of the lime application method and dose on $\mathrm{pH}, \mathrm{Al}^{+3}, \mathrm{~V} \%$ and $\mathrm{Ca}+\mathrm{Mg}$ in the soil and on dry matter yield of alfalfa cultivated under a consolidated no-tillage system. The experiment was conducted at the Experimental Station of Paraná Agronomic Institute, located in Pato Branco city, in Paraná state. The plots consisted of the types of lime application (plowing+harrowing, subsoil and surface), the sub-plots was the lime dose $(0,2,4,6$ and $\left.8 \mathrm{Mg} \mathrm{ha}^{-1}\right)$ and the sub-sub-plots were the sampled soil depth $(0-5 ; 5-10 ; 10-20$ and 20-30 cm). The results show the application of lime, even superficially, caused increases in $\mathrm{pH}$, concentration of $\mathrm{Ca}$ and $\mathrm{Mg}$ and base saturation of the soil, while also reducing the concentration of Al, especially in the surface layers of the soil. The practice of plowing and harrowing or of subsoiling, with the aim of lime incorporation in a consolidated no-tillage system is unnecessary. If it is required, the application of lime to the soil should be done superficially for alfalfa cultivated in this system.
\end{abstract}

Key words: Acidity and liming. Liming superficial application. Liming recommendation. Bases saturation.

\begin{abstract}
RESUMO - A alfafa (Medicago sativa L.) é uma das plantas mais exigentes em nutrientes e em fertilidade do solo. Por sua vez, o Brasil possui solos ácidos que podem reduzir o potencial produtivo das culturas. Recomenda-se que o calcário seja incorporado ao solo, contudo em sistemas de plantio direto isto é desaconselhado. Este trabalho tem por objetivo avaliar doses e formas de aplicação de calcário para alfafa cultivada em sistema plantio direto consolidado. O experimento foi conduzido na Estação Experimental do Instituto Agronômico do Paraná, localizada no Município de Pato Branco - PR. As parcelas constituíram-se das formas de aplicação de calcário (superficial, subsolador, aração+gradagem), as sub-parcelas pelas doses de calcário (0; 2; 4; 6 e $\left.8 \mathrm{Mg} \mathrm{ha}^{-1}\right)$ e as sub-subparcelas pelas profundidades de solo amostradas $(0-5 ; 5-10 ; 10-20$ e 20-30 cm). Os resultados mostraram que a aplicação de calcário, provocou aumentos de $\mathrm{pH}$, dos teores de $\mathrm{Ca}$ e de $\mathrm{Mg}$ e da saturação por bases do solo até a camada de 20-30 cm de profundidade. Em geral não se constatou influência da forma de aplicação de calcário sobre a taxa de acúmulo de matéria seca. Não houve resposta da taxa de acúmulo diária da alfafa com doses de calcário superiores a $2 \mathrm{Mg} \mathrm{ha}^{-1}$. A prática de aração e gradagem ou de subsolagem, visando à incorporação de calcário no sistema de plantio direto consolidado, é desnecessária recomendando-se que a aplicação de calcário no solo seja feita de forma superficial.
\end{abstract}

Palavras-chave: Acidez e calagem. Aplicação superficial de calcário. Recomendação de calagem. Saturação por bases.

\footnotetext{
*Autor para correrspondência

${ }^{1}$ Recebido para publicação em 16/04/2014; aprovado em 26/06/2014

Parte do Dissertação de Mestrado da primeira autora apresentada no Programa de Pós-Graduação em Agronomia, Universidade Tecnológica Federal do Paraná

${ }^{2}$ Programa de Pós-Graduação em Agronomia, Universidade Tecnológica Federal do Paraná, Campus Pato Branco-PR, Brasil, leticia @ zootecnista.com.br ${ }_{3}^{3}$ Departamento de Agronomia, Universidade Tecnológica Federal do Paraná, Campus Pato Branco, Via do Conhecimento, Km 1, Pato Branco-PR, Brasil, 85.503-390.tangriani@utfpr.edu.br, cassol@utfpr.edu.br

${ }^{4}$ Programa de Produção Animal, Intituto Agronômico do Paraná, Estação Experimental de Pato Branco, Pato Branco-PR, Brasil, assmann@ iapar.com.br ${ }^{5}$ Zootecnista autonomo, rodolfo@vividense.com.br

${ }^{6}$ Lavoura Indústria Comércio Oeste S/A, Pato Branco-PR, Brasil, viniciusnicola@ @otmail.com

${ }^{7}$ Programa de Pós-Graduação em Produção Vegetal, Universidade Federal do Paraná, Pato Branco-PR, Brasi, jussaraferrazza@ yahoo.com.br
} 


\section{INTRODUCTION}

Alfalfa is a perennial forage legume, and is considered the "queen of forages" due to its high nutritional value, good productivity and acceptability to animals. The crop is capable of high yields, reaching $20 \mathrm{Mg} \mathrm{ha}^{-1} \mathrm{yr}^{-1}$ of dry matter under non-limiting conditions (BROWN, 2003).

The problem that limits the adaptation of alfalfa to Brazilian conditions to the greatest extent is the soil, as the crop, according to the recommendations of Rassini (2003), should be grown in soils that have a $\mathrm{pH}$ of between 6.5 and 7.0. However, in Brazil 70\% of the soils are acidic in character, which can lead to a reduction in the productive potential of the crop by around 40\% (QUAGGIO, 2000). Therefore, if the production potential of the alfalfa crop is to be maximized it is essential to correct the soil acidity through the practice of liming.

No-tillageis the dominant soilmanagement system in Brazil, where it occupied an area of approximately 32 million hectares during the 2011/2012 harvest (FEBRAPDP, 2012). Technical recommendations indicate that lime application should be incorporated; however, this conflicts with the recommendations for no-tillage, which discourage practices that promote the disturbance of the soil. Although a number of studies have indicated the success of surface lime application (without soil incorporation) in no-tillage systems, this topic is still under studied for crops that are highly demanding on $\mathrm{pH}$, as is the case with alfalfa.

Caires et al. (2006), Caires et al. (2008) and Rheinheimer et al. (2000) found that surface lime application promoted an increases in crop yields, which varied according to species, soil type, fertility conditions and the tillage system implemented. Rechcigl et al. (1985) observed that alfalfa showed a production increase in excess of $100 \%$ through the application of lime to the soil surface. Furthermore, studies conducted in Brazil have shown increases to $\mathrm{pH}$ and to the concentration of exchangeable calcium and magnesium (CAIRES et al., 2006; CAIRES et al., 2008; COSTA and ROSOLEM, 2007), as well as the reduction of exchangeable aluminum in subsoil layers after a surface application of lime (CAIRES; BANZATTO; FONSECA, 2000; PETRERE and ANGHINONI, 2001).

Therefore, this study aimed to evaluate the effects of the lime application method and dose on $\mathrm{pH}$, $\mathrm{Al}^{+3}, \mathrm{~V} \%$ and $\mathrm{Ca}+\mathrm{Mg}$ in the soil and on dry matter yield of alfalfa cultivated under a consolidated notillage system.

\section{MATERIAL AND METHODS}

The experiment was conducted in an area of dystrophic Typic Red Latosol (Oxisol), with an undulating relief and clayey texture (BHERING et al., 2008), at the Experimental Station of the Agronomic Institute of Paraná (IAPAR), located in the municipality of Pato Branco - PR. The area is part of the physiogeographical region of Terceiro Planalto Paranaense, between the coordinates of $25^{\circ} 07^{\prime}$ latitude South and $52^{\circ} 41^{\prime}$ longitude West, with a mean altitude of $700 \mathrm{~m}$. For more than fifteen years the experimental area was under no-tillage, with crops of corn in rotation with soybean in the summers, while the rotation of winter cereals with forage turnip was employed in the winter. The present study started in 2010 and was run until 2012. Table 1 presents the chemical characteristics of the soil, collected before the establishment of the experiment in February 2010.

The climate, according to the Köppen classification, is a Cfa in transition to Cfb (MAAK, 1968). The rainfall over the last ten years has varied between 1578-3101 $\mathrm{mm}$ per year and the mean maximum and minimum temperatures were 25 and $14.2{ }^{\circ} \mathrm{C}$ respectively.

In July 2010 the stipulated lime doses were applied, following this plowing+harrowing or subsoiling was conducted, depending on whether incorporation was required as part of the treatment regime. Dolomitic limestone $(\mathrm{CaO}=$ $28 \%$; $\mathrm{MgO}=20 \%$ ) was utilized for the application, with a effective calcium carbonate equivalent (ECCE) of $80 \%$, the doses used were converted to values of $100 \%$ of the RPTN.

The cultivar utilized was Crioula, at a density of $20 \mathrm{~kg} \mathrm{ha}^{-1}$ of seeds. The seeds were inoculated during sowing with Rhizobium meliloti. The sowing of alfalfa was conducted on the 27 th September 2010, under a no-tillage system, using a plot seeder with a line spacing of $23 \mathrm{~cm}$. Fertilization sowing was done with the application of $40 \mathrm{~kg} \mathrm{ha}^{-1}$ of $\mathrm{K}_{2} \mathrm{O}$ and $120 \mathrm{~kg} \mathrm{ha}^{-1}$ of $\mathrm{P}_{2} \mathrm{O}_{5}$, repeated once a year, following the recommendations of CQFS - RS/SC (2004).

The experiment consisted of a randomized block design with four replications in a split-plot scheme constituting a $3 \times 5 \times 4$ factorial set, resulting in 60 treatments per block. The plots consisted of the types of lime application (plowing+harrowing, subsoil and surface), the sub-plots was the lime dose $\left(0,2,4,6\right.$ and $\left.8 \mathrm{Mg} \mathrm{ha}^{-1}\right)$ and the subsub-plots were the sampled soil depth $(0-5 ; 5-10 ; 10-20$ and $20-30 \mathrm{~cm})$. The depth of soil affected by the disk plowing and harrowing process was 25 to $30 \mathrm{~cm}$, and the depth reached by the subsoiler was $30 \mathrm{~cm}$.

The criteria used to define the dose of lime was established through the Base Saturation method. In the calculation it was stipulated that $80 \%$ would be the final value of Base Saturation to be achieved (V2), which resulted in a recommendation of $2.8 \mathrm{Mg} \mathrm{ha}^{-1}$. 
Table 1 - Chemical attribute of the soil prior to the start of the experiment

\begin{tabular}{lccccccccc}
\hline \multicolumn{1}{c}{ Soil Layer } & $\mathrm{pH}$ & $\mathrm{OM}^{1}$ & $\mathrm{Ca}$ & $\mathrm{Mg}$ & $\mathrm{Al}$ & $\mathrm{H}+\mathrm{Al}$ & $\mathrm{K}$ & $\mathrm{P}^{2}$ & $\mathrm{BS}$ \\
\hline \multicolumn{1}{c}{$\mathrm{cm}$} & $\mathrm{CaCl}_{2}$ & $\mathrm{~g} \mathrm{dm}^{-3}$ & ------------------ & $\mathrm{cmol}_{\mathrm{c}} \mathrm{dm}^{-3}---------------$ & $\mathrm{mg} \mathrm{dm}^{-3}$ & $\%$ \\
\hline 0 a 10 & 5,4 & 42,8 & 6,44 & 2,81 & 0,00 & 3,97 & 0,63 & 31,5 & 71 \\
10 a 20 & 4,8 & 40,2 & 3,75 & 1,87 & 0,18 & 5,35 & 0,50 & 6,9 & 53 \\
20 a 40 & 4,6 & 29,5 & 1,91 & 1,26 & 0,47 & 5,35 & 0,20 & 2,7 & 40 \\
Média 0-20 & 5,1 & 41,5 & 5,10 & 2,34 & 0,09 & 4,66 & 0,56 & 19,2 & 62 \\
\hline
\end{tabular}

$\mathrm{OM}=$ Organic matter; $\mathrm{BS}=$ Base saturation; 1 = Walkley-Black; 2 = Mehlich-1

On the $20^{\text {th }}$ August 2012, 25 months after the application of lime, with the objective of chemical characterization of the soil, two subsamples from each subplot were collected in order to obtain a representative composite sample. The layers sampled were: 0-5, 5-10, 10-20 and 20-30 cm. Samples taken until the depth of $20 \mathrm{~cm}$ were collected using a spade, while those from 20 to $30 \mathrm{~cm}$ were taken with an auger, subsequent chemical analysis was conducted according to the methodology described by Pavan et al. (1992).

The production of dry matter(DM) was determined by sampling plants from a $0.25 \mathrm{~m}^{2}$ area in each plot. On the 07/04/2011 the first cut (the standardization cut) was taken when the plants were in full bloom (above $50 \%$ flowering). Following this, the alfalfa was cut back to $10 \mathrm{~cm}$ above ground level when bloom had reached approximately $10 \%$. The cuts were made on the 56, $116,144,184,220,248,286,322,353,391,432,485$, 530,574 and 597 day after the standardization cut. The collected material was put in an oven at $60^{\circ} \mathrm{C}$ until a constant weight was achieved to determine the amount of dry matter. After the evaluation of DM the plots were cut to leave $10 \mathrm{~cm}$ of plant material above the soil level, subsequently the green material left after cutting was removed from the plots.

The accumulated production of dry matter was acquired through the sum of dry matter obtained at each cut. The rate of accumulation of dry matter was calculated between the cuts by dividing the production of dry matter by the number of days between assessments.

The results of the assessments were subjected to analysis of variance. The variances were first evaluated by the Bartlett test for homogeneity. The variables that showed homogeneity had their treatments evaluated by F-Test. When the results showed significance at the 5 or $1 \%$ probability level, the means of the qualitative factors (Method of application and Soil sample depth) were compared by the Minimum Significant Difference, at $5 \%$ probability. For the quantitative factor (dose of lime), the equations that were significant by $\mathrm{F}$ Test were fitted with a polynomial regression, modelling the relationship between the doses of lime (independent variable) and the dependent variables using the model that best expressed the relationship. Linear and quadratic models were tested and the choice was made based on the significance of the coefficient of determination (less than $8 \%$ ).

\section{RESULTS AND DISCUSSION}

\section{Soil Attributes}

A three-way interaction effect was observed between Application method X Lime dose X Soils sample depth on the soil $\mathrm{pH}$, after 25 months of liming (Figure 1). The surface liming resulted in the most elevated of the $\mathrm{pH}$ values in the deepest soil layer sampled, when compared with the other methods of application. Similar results were found in studies by Alleoni, Cambri and Caires (2005); Caires and Rosolem (1998), which demonstrated increases in the $\mathrm{pH}$ and in the concentration of exchangeable $\mathrm{Ca}$ and $\mathrm{Mg}$ below the region of liming. It highlights that the operation of plowing and harrowing affects the soil to a maximum depth of $25-30 \mathrm{~cm}$ and, probably cause disturbance in this layer of the soil. In the plots where the lime was applied superficially or incorporated with a subsoiler, the presence of intact preferential channels probably facilitated the descent of $\mathrm{Al}^{+3}$ neutralizing substances into the deepest soil layers, elevating the $\mathrm{pH}$.

These results agree with those found by Fidalski and Tormena (2005) who studied surface liming where there was progression towards correcting the acidity of the soil in the $5-10 \mathrm{~cm}$ layer, wherein the $\mathrm{pH}$ rose to a maximum value of 6.1 with $6.4 \mathrm{Mg} \mathrm{ha}^{-1}$ of lime. This was also similar to the results found by Petrere and Anghinoni (2001), Caires, Banzatto and Fonseca (2000), who, in research conducted on the application of lime to the soil surface, observed changes in the $\mathrm{pH}$ values in the subsurface layers, reaching up to $60 \mathrm{~cm}$ in depth. 
Figure 1 - Actual acidity $(\mathrm{pH})$ of soil planted with alfalfa due to method of lime application
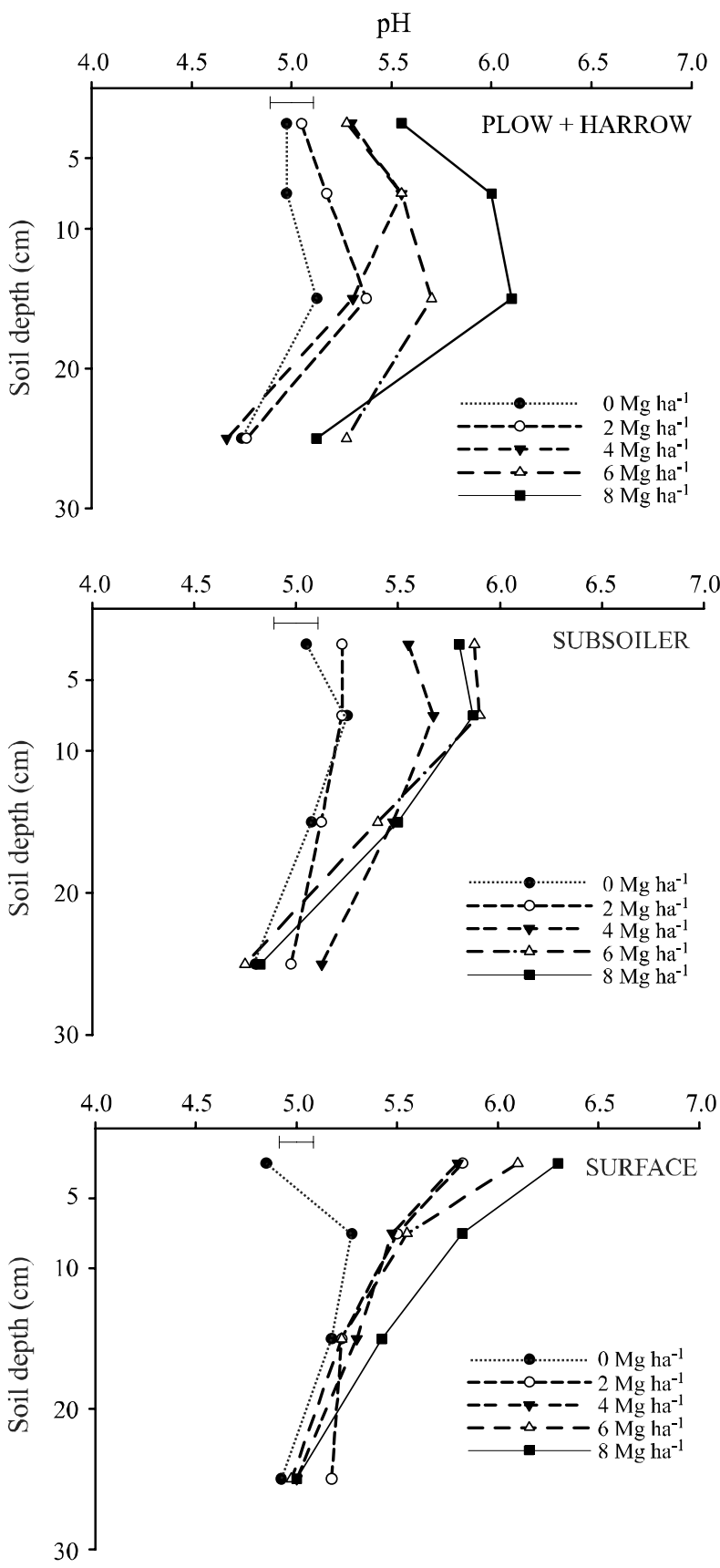

Horizontal bars compare application methods and doses of lime at the same depth through the Least Significant Difference test $(\mathrm{p}<0.05)$; (Plow + Harrow; Subsoiler and Surface), lime dose and soil sample depth

Amaral et al. (2004) and Petrere and Anghinoni (2001) identified particles of lime below the region of application, that migrated via ducts formed by macropores, which would result in the correction of the acidity with the increase of the $\mathrm{pH}$. This neutralizing front, advances through the profile, altering some soil properties, the rate of progression depends on the dose applied, the time elapsed and the soils own physical and chemical properties (GATIBONI et al., 2003; MOREIRA et al., 2001).

A significant influence was found for the interaction Lime dose X Method of application on $\mathrm{Al}^{+3}$ in the soil (Figure 2). It was observed, that after 25 months of liming application the dose $2 \mathrm{Mg} \mathrm{ha}^{-1}$, when applied superficially, practically neutralized all of the exchangeable $\mathrm{Al}\left(0.004 \mathrm{cmol}_{\mathrm{c}} \mathrm{dm}^{-3}\right)$. Whereas, the same dose applied via Plow + Harrow caused a smaller reduction in the Al level $\left(0.069 \mathrm{cmol}_{\mathrm{c}} \mathrm{dm}^{-3}\right)$. It was found that performing plowing and harrowing at the highest lime dose applied $\left(8 \mathrm{Mg} \mathrm{ha}^{-1}\right)$ induced a marked reduction of the $\mathrm{Al}$, however, no significant difference was observed for the Al level between the different methods of application.

Figure 2 - Soil exchangeable aluminium as a function of dose and application method of lime, after 25 months of liming

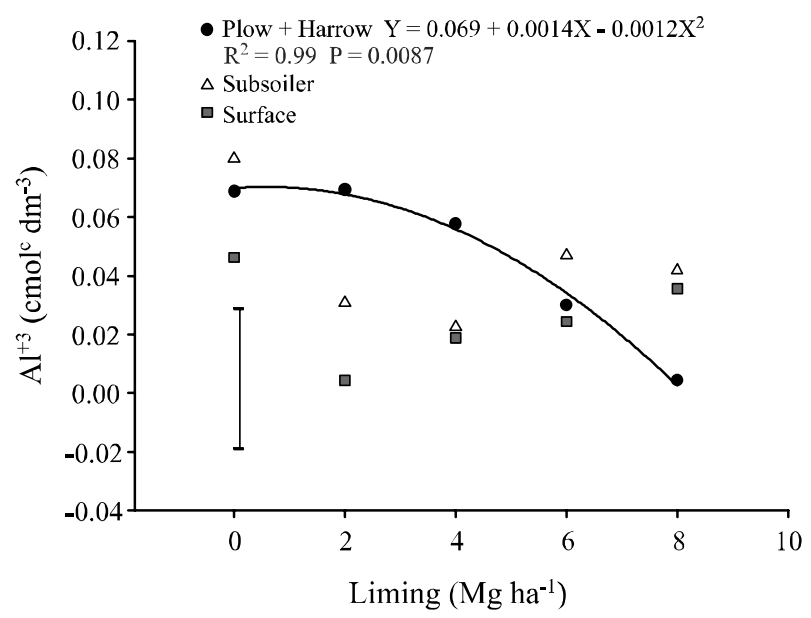

The vertical bar compares the Minimum Significant Difference $(p<0.05)$ of the application methods of lime at the same dose

These results confirm that liming, even when superficial, can neutralize the toxic effect of $\mathrm{Al}^{+3}$. According to Kaminski et al. (2005) surface liming benefits from the soil not being disrupted, as this maintains the channels and biopores that allow the acidity neutralizing action to happen at depth. Furthermore, according to Costa and Rosolem (2007) the toxic $\mathrm{Al}$ in the soil can be complexed by low molecular weight organic acids, which result from the decomposition of plant residues, of which citric, oxalic and tartaric acid are the most effective. 
We observed a significant influence for Lime dose $\mathrm{X}$ Soil sample depth on the base saturation in the soil. As shown in Figure 3A, the application of increasing doses of lime caused an increase in the values of base saturation at the depths of 0-5, 5-10 and 10-20 cm. Whereas, even after 25 months of lime application, the increase of base saturation values caused by lime application at the depths of soil 20-30 cm, were lower when compared to shallower soil depths, independent of the application method used. Studies conducted by Caires et al. (2002), Freiria et al. (2008) and Prado and Barion (2009) found that an increase in the base saturation can be caused by an increase in the lime dose.

As seen in Figure 3B the method of lime application influenced the values of base saturation at the sampling depth $0-5 \mathrm{~cm}$. At this depth the plots in which the lime was not incorporated (surface application) presented a level of base saturation of $73 \%$. While, in the plots in which the lime was incorporated by plowing + harrowing, the value was found to be $63 \%$. This can be explained by the larger amount of lime that is present in topsoil. However, even though there was no significant difference at the $20-30 \mathrm{~cm}$ depth, the highest values of base saturation were found when the soil was not plowed, namely, for the surface liming. It is notworthy that for the treatment of plowing+harrowing the values of the V\% were uniform in the layer of soil $0-20 \mathrm{~cm}$ in depth, due to the action of the implements. Freiria et al. (2008) also found a reduction in the base saturation with increasing depth of the soil profile, and that this reduction was more pronounced when the lime was applied to the surface.

Similar results were found in studies conducted by Caires et al. (2006) and Caires et al. (2008), where it was noticed that the surface liming promoted a large increase in the $\mathrm{pH}$, exchangeable $\mathrm{Ca}+\mathrm{Mg}$ and base saturation and a reduction in the potential acidity $(\mathrm{H}+\mathrm{Al})$, up to $10 \mathrm{~cm}$ in depth, in the sampling conducted 12 months after liming.

The recommendations for base saturation and for the $\mathrm{pH}$ suitable for the cultivation of alfalfa in Brazil were established before the consolidation of the notillage system. Because of this, some recommendations stipulate indices of base saturation ( $\mathrm{V} \%$ ) for alfalfa as above $95 \%$ for the $0-20 \mathrm{~cm}$ layer, which is an extremely high value. Others recommend correcting the acidity, both at the formation and while maintaining the area of alfalfa, at the value of $80 \%$ (WERNER et al., 1996).

When calculating, by weighted average, what would be the mean values of $\mathrm{pH}$ and base saturation obtained at the $0-20 \mathrm{~cm}$ depth of soil, after 25 months of lime application, it was found that these attributes were only influenced by the lime dose, with the method of application not affecting these values.

However, even at the highest dose $\left(8 \mathrm{Mg} \mathrm{ha}^{-1}\right)$, it was observed that the maximum value of $\mathrm{pH}$ and of base saturation achieved was 5.7 and $71.2 \%$, respectively, which are inferior values to those recommended in the current technical recommendations for the cultivation of alfalfa in Brazil.

The elevated values advocated by the Brazilian technical recommendations, such as in Baligar, Elgin and Foy (1989), who recommend a $\mathrm{pH}$ value from 6.0 to 7.5 as ideal for cultivating alfalfa, were not adapted for the soil conditions resulting from no-tillage and, thereby, due to their extremely elevated values discourage the adoption of cultivation of this legume.

An interaction effect of lime dose $\mathrm{X}$ soil sample depth on the concentration of $\mathrm{Ca}+\mathrm{Mg}$ in the soil was

Figure 3 - Base saturation of the soil due to soil sample depth and lime doses (A), and method of lime application (B), after 25 months
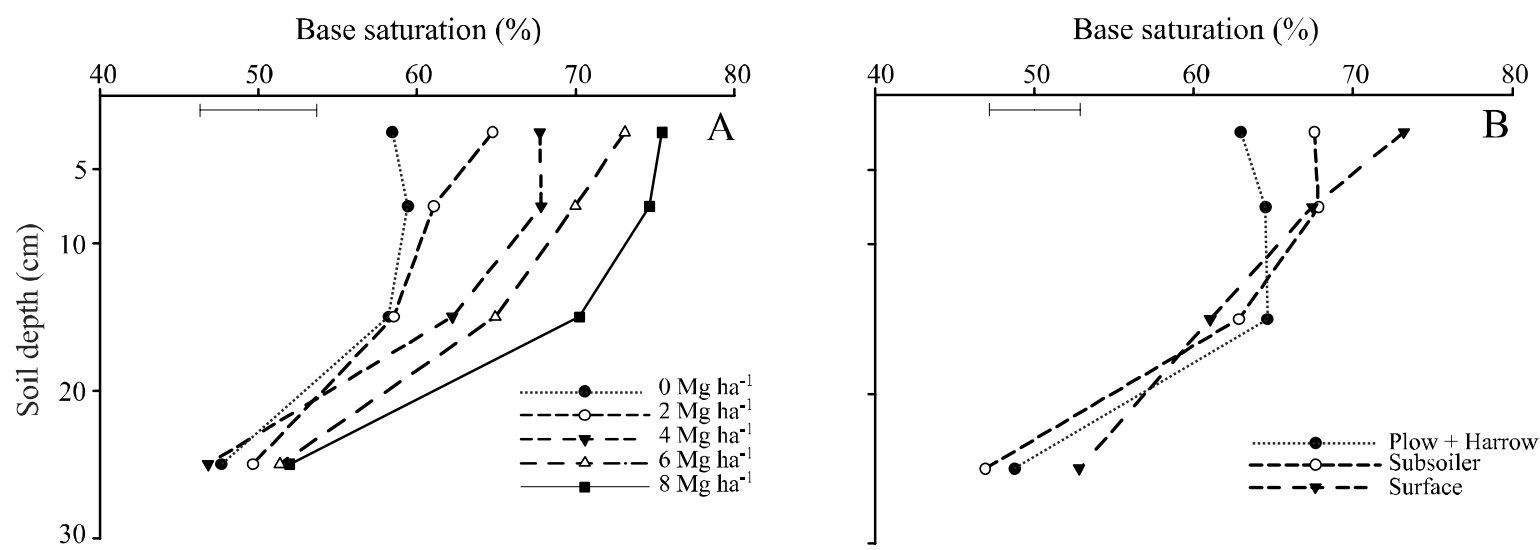

Horizontal bars compare the Minimum Significant Difference ( $\mathrm{p}<0.05)$ effect of lime dose (A) and application method (B) at the same depth 
found. It can be seen in Figure $4 \mathrm{~A}$ that the greatest observed value for exchangeable $\mathrm{Ca}+\mathrm{Mg}$ was for the dose of $8 \mathrm{Mg} \mathrm{ha}^{-1}$ at the depth of $0-5 \mathrm{~cm}\left(10.97 \mathrm{cmol}_{\mathrm{c}}\right.$ $\left.\mathrm{dm}^{-3}\right)$. Although this value did not differ significantly from the value found at the depth of $5-10 \mathrm{~cm}$ for the dose of $8 \mathrm{Mg} \mathrm{ha}^{-1}\left(10.72 \mathrm{cmol}_{\mathrm{c}} \mathrm{dm}^{-3}\right)$. As the lime dose increased it was observed that there was a gradual increase in the concentration of $\mathrm{Ca}+\mathrm{Mg}$ within each sample depth, except at the $20-30 \mathrm{~cm}$ depth (Figure 4A). One of the benefits of liming is the elevation of $\mathrm{Ca}$ $+\mathrm{Mg}$, with the higher the quantity of lime the greater the concentrations of these cations in the soil. These results are similar to those obtained by Moreira and Fageria (2010) and Prado and Barion (2009) who found increased concentration of calcium and magnesium in the soil with an increased lime dose. According to Moreira and Fageria (2010) this occurred because dolomitic lime is a source of calcium and magnesium.

Moreover, it was observed that the greater the depth of the soil profile the lower the concentration of $\mathrm{Ca}+\mathrm{Mg}$, due to the low mobility of the lime, highlighting that this effect is independent of the method of application used.

An effect of the method of lime application on the concentration of $\mathrm{Ca}+\mathrm{Mg}$ in the $0-5 \mathrm{~cm}$ soil depth was found (Figure 4B). The highest values for the concentration of $\mathrm{Ca}+\mathrm{Mg}\left(11.02 \mathrm{cmol}_{\mathrm{c}} \mathrm{dm}^{-3}\right)$ were seen to be when the lime was applied superficially. This can be explained by the fact that, even independent of the dose used, the highest concentration of lime stayed at the surface of the soil and was responsible for the elevated values of $\mathrm{Ca}+\mathrm{Mg}$. However, it was observed that in the other sample depths, especially the deepest, namely $20-30 \mathrm{~cm}$ there was no significant difference between the methods of liming, proving that there is no need in incorporating it.

Increases in $\mathrm{Ca}$ and $\mathrm{Mg}$ in the lowest layers of the soil, even when the lime was applied to the surface, were observed by Caires et al. (2006), Caires et al. (2008); Ciotta et al. (2004) and Costa and Rosolem (2007), this shows that despite the low mobility of the cations $\mathrm{Ca}^{+2}$ and $\mathrm{Mg}^{+2}$, due to the low solubility of the lime distributed on the soil surface, the decomposition of plant residues produce water-soluble organic complexes capable of forming complexes with $\mathrm{Ca}^{+2}$ and $\mathrm{Mg}^{+2}$, which elevate the dissolution of lime and its mobility in the soil profile.

\section{Attributes of the plant}

For the evaluation period, June 2011 to December 2012 (1.5 years), the total production of dry matter was $45.427 \mathrm{~kg} \mathrm{ha}^{-1}$, but this accumulation was not influenced by lime dose nor method of application. This number is much higher than the potential dry matter production estimated for alfalfa in the literature $\left(22 \mathrm{Mg} \mathrm{ha}^{-1} \mathrm{yr}^{-1}\right)$, however, this value is difficult to obtain, due to environmental (PAIM, 1994) and management limitations. Heinemann et al. (2006) found that, for the Crioula cultivar, the production was $13,274 \mathrm{Mg} \mathrm{ha}^{-1} \mathrm{yr}^{-1}$, whereas Monteiro, Costa and Silveira (1998) observed the value of $12,980 \mathrm{Mg} \mathrm{ha}^{-1} \mathrm{yr}^{-1}$. It was noted that for the period of this study, one and a half years of evaluation, the production values of alfalfa were superior to those reported in the literature, even when the lime was applied on the soil surface.

Figure 4 - Soil $\mathrm{Ca}+\mathrm{Mg}$ concentration as a function of soil sample depth and lime dose (A) and method of lime application (B), after 25 months of liming
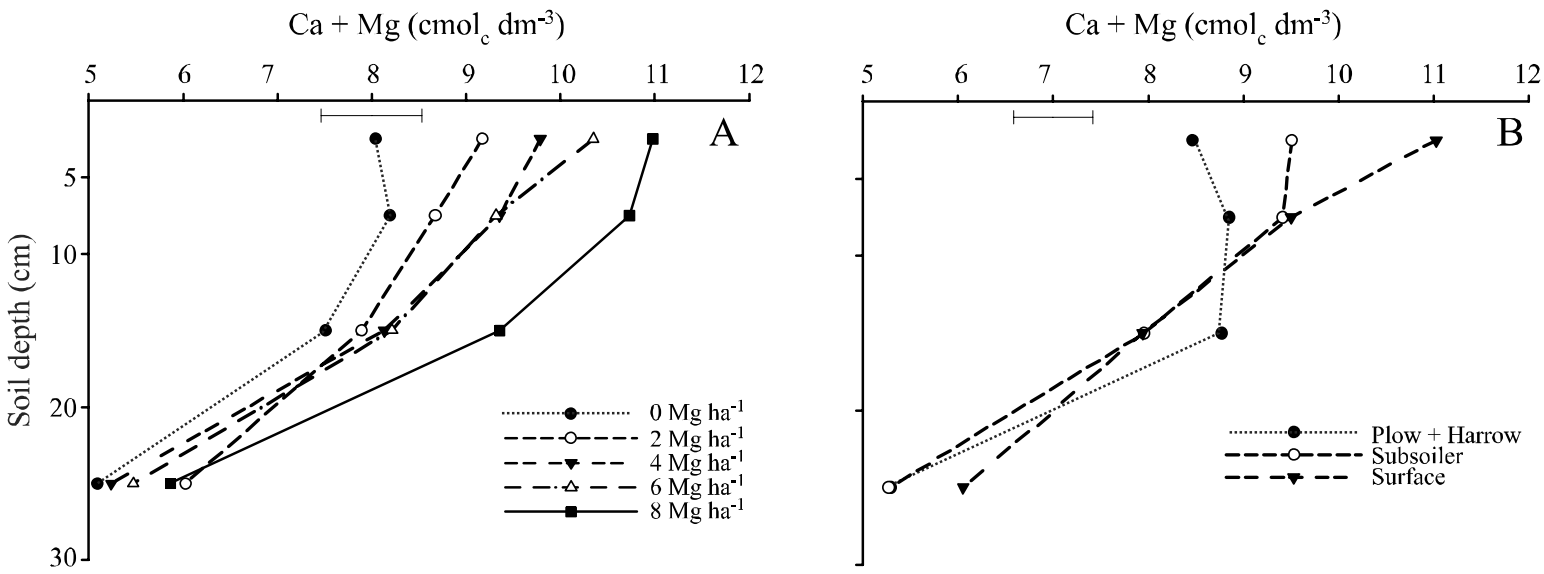

Horizontal bars compare the Minimum Significant Difference $(\mathrm{p}<0.05)$ effect of application method (A) and dose of lime (B) at the same depth 
When evaluating the daily accumulation rate an interaction effect of Accumulation Days $\mathrm{X}$ Method of Lime Application was observed, during the fifteen periods of evaluation, independent of the lime dose (Figure 5). Only 220 days into the experiment (November/2011), it was found that lime application via plowing and harrowing $\left(102 \mathrm{~kg} \mathrm{ha}^{-1} \mathrm{day}^{-1}\right)$ presented values statistically higher than those plots where lime was applied superficially $\left(90 \mathrm{~kg} \mathrm{ha}^{-1} \mathrm{day}^{-1}\right)$. The highest dry matter accumulation rate of the experiment was observed after 597 days of evaluation (December 2012) and corresponded to a dry matter accumulation rate of $120 \mathrm{~kg} \mathrm{ha}^{-1} \mathrm{day}^{-1}$, independent of the method of lime application. The lowest rate of accumulation was observed on days 56 and 116 of the evaluation, where the mean of both corresponded to an accumulation rate of $24 \mathrm{~kg} \mathrm{ha}^{-1} \mathrm{day}^{-1}$ of alfalfa dry matter.

Figure 5 - Influence of accumulated days and methods of lime application on the daily accumulation rate of alfalfa

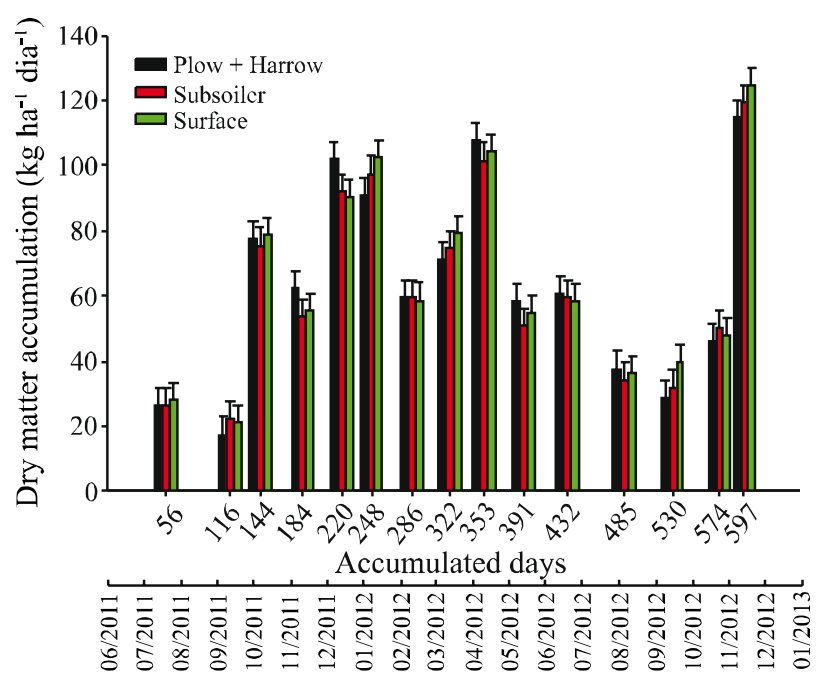

Non-overlapping bars indicate means differing by the Minimum Significant Difference test at $5 \%$ probability

It was observed, therefore, that even with alfalfa being one of the plants most demanding on soil fertility, notably in terms of neutralization of $\mathrm{Al}$ and the need of elevated concentration of base saturation, the distinct methods of application did not influence plant productivity (accumulation of dry matter).

It was found that regardless of application method, the lime dose influenced the rate of dry matter accumulation. Although, the maximum technical efficiency was established with the lime application of $5.9 \mathrm{Mg} \mathrm{ha}^{-1}\left(\mathrm{Y}=60.4+1.9 \mathrm{X}-0.164 \mathrm{X}^{2}\right.$,
$\left.\mathrm{P}=0.075, \mathrm{R}^{2}=0.92\right)$, which would result in a dry matter accumulation rate of $66 \mathrm{~kg} \mathrm{ha}^{-1} \mathrm{day}^{-1}$. It was observed that for the lime application of $2 \mathrm{Mg} \mathrm{ha}^{-1}$, the accumulation rate obtained was $64 \mathrm{~kg} \mathrm{ha}^{-1}$ day, a value which differs little from that obtained through the application of the dose of maximum technical efficiency, which in this case can be recommended as the $2 \mathrm{Mg} \mathrm{ha}^{-1}$ of lime, regardless of the application method.

\section{CONCLUSIONS}

1. The application of lime, even superficially, caused increases in $\mathrm{pH}$, concentration of $\mathrm{Ca}$ and $\mathrm{Mg}$ and base saturation of the soil, while also reducing the concentration of $\mathrm{Al}$, especially in the surface layers of the soil;

2. The values currently recommended for $\mathrm{pH}$ and base saturation for the cultivation of alfalfa in Brazil are overestimated, which discourages the growing of this crop;

3. The practice of plowing and harrowing or of subsoiling, with the aim of lime incorporation in a consolidated no-tillage system is unnecessary. If it is required, the application of lime to the soil should be done superficially for alfalfa cultivated in this system.

\section{ACKNOWLEDGEMENT}

The authors wish to tank FINEP, Fundação Araucária and $\mathrm{CNPq}$ for their financial and logistical support.

\section{REFERENCES}

ALlEONI, L. R. F.; CAMBRI, M. A.; CAIRES, E. F. Atributos químicos de um Latossolo de cerrado sob plantio direto, de acordo com doses e formas de aplicação de calcário. Revista Brasileira de Ciência do Solo, v. 29, p. 923-934, 2005.

AMARAL, A. S. et al. Movimentação de partículas de calcário no perfil de um cambissolo em plantio direto. Revista Brasileira de Ciência do Solo, v. 28, p. 359-367, 2004.

BALIGAR, V. C.; ELGIN JR., J. H.; FOY, C. D. Variability in alfafa for growth and mineral uptake and efficiency ratios under aluminum stress. Agronomy Journal, v. 81, p. 223229, 1989. 
BHERING, S. B. et al. Mapa de solos do Estado do Paraná: legenda atualizada. Rio de Janeiro: EMBRAPA/IAPAR, $2008.74 \mathrm{p}$.

BROWN, H. E.; MOOT, D. J.; POLLOCK, K. M. Long term growth rates and water extraction patterns of dryland chicory, lucerne and red clover. In: Moot DJ ed. Legumes for dryland pastures. New Zealand Grassland Association, Research Practice Series, v. 11, p. 91-99, 2003.

CAIRES, E. F.; ROSOLEM, C. A. Correção da acidez do solo e desenvolvimento do sistema radicular do amendoim em função da calagem. Bragantia, v. 57, p. 175-184, 1998.

CAIRES, E. F.; BANZATTO, D. A.; FONSECA A. F. Calagem na superfície em sistema de plantio direto. Revista Brasileira de Ciência do Solo, v. 24, p. 161-169, 2000.

CAIRES, E. F. et al. Correção da acidez do solo, crescimento radicular e nutrição do milho de acordo com a calagem na superfície em sistema plantio direto. Revista Brasileira de Ciência do Solo, v. 26, p. 1011-1022, 2002.

CAIRES, E. F. et al. Surface application of lime ameliorates subsoil acidity and improves root growth and yield of wheat in an acid soil under no-till system. Scientia Agricola, v. 63, p. 502-509, 2006.

CAIRES, E. F. et al. Soil acidity and aluminium toxicity as affected by surface liming and cover oat residues under a no-till system. Soil Use Management, v. 24, p. 302-309, 2008.

CIOTTA, M. N. et al. Manejo da calagem e os componentes da acidez de Latossolos Bruno em plantio direto. Revista Brasileira de Ciência do Solo, v. 28, p. 317-326, 2004.

COMISSÃO DE QUÍMICA E FERTILIDADE DO SOLO. Manual de adubação e calagem para os Estados do Rio Grande do Sul e Santa Catarina, 10. ed., Porto Alegre: SBCS, 2004. 400 p.

COSTA, A.; ROSOLEM, C. A. Liming in the transition to notill under a wheat-soybean rotation. Soil Tillage Research, v. 97, p. 207-217, 2007.

FEBRAPDP. Disponível em:< http://www.febrapdp.org. br/download/PD_Brasil_2013. I. pdf >. Acesso em: 30 dez. 2012.

FIDALSKI, J.; TORMENA, C. A. Dinâmica da calagem superficial em um Latossolo Vermelho distrófico. Revista Brasileira de Ciência do Solo, v. 29, p. 235-247, 2005.

FREIRIA, A. C. et al. Alterações em atributos químicos do solo pela aplicação de calcário na superfície ou incorpo-rado. Acta Scientiarum Agronomy, v. 30, p. 285-291, 2008.

GATIBONI, L. C. et al. Alterações dos atributos químicos de solo arenoso pela calagem superficial no sistema plantio direto consolidado. Ciência Rural, v. 33, p. 283-290, 2003.

HEINEMANN, A. B. et al. Avaliação de cultivares de alfafa na região central do estado de goiás. Ciência Animal Brasileira, v. 7, p. 257-263, 2006.
KAMINSKI, J. et al. Eficiência da calagem superficial e incorporada precedendo o sistema plantio direto em um argissolo sob pastagem natural. Revista Brasileira de Ciência do Solo, v. 29, p. 573-580, 2005.

MAAK, R. Geografia física do Estado do Paraná. Curitiba, 1968. $350 \mathrm{p}$.

MONTEIRO, A. L. G.; COSTA, C.; SILVEIRA, A. C. Produção e distribuição de matéria seca e composição bromatológica de cultivares de alfafa (Medicago sativa L.). Revista Brasileira de Zootecnia, v. 27, p. 868-874, 1998.

MOREIRA, A.; FAGERIA, N. K. Liming influence on soil chemical properties, nutritional status and yield of alfalfa grown in acid soil. Revista Brasileira de Ciência do Solo, v. 34, p. 1231-1239, 2010.

MOREIRA, S. G. et al. Calagem em sistema de semeadura direta e efeitos sobre a acidez do solo, disponibilidade de nutrientes e produtividade de milho e soja. Revista Brasileira de Ciência do Solo, v. 25, p. 71-81, 2001.

PAIM, N. R. Utilização e melhoramento da alfafa. In: Workshop sobre potencial forrageiro da alfafa (Medicago sativa L.) nos trópicos, Juiz de Fora, 1994. Anais. Juiz de Fora: Embrapa-CNPGL, p. 141-158, 1994.

PAVAN, M. A. et al. Manual de análise química de solo e controle de qualidade. Londrina: IAPAR, 1992. 40 p. (IAPAR. Circular 76 ).

PETRERE, C.; ANGHINONI, I. Alterações de atributos químicos no perfil do solo pela calagem superficial em campo nativo. Revista Brasileira de Ciência do Solo, v. 25, p. 885-895, 2001.

PRADO, R. M.; BARION, R. D. Efeitos da calagem na nutrição e produção de massa seca de capim tifon 85 . Pesquisa Agropecuária Tropical, v. 39, p. 218-224, 2009.

QUAGgio, J. A. Acidez e calagem em solos tropicais. Campinas: Instituto Agronômico, 2000. 111 p.

RASSINI, J. B. et al. Cultivo de alfafa: característica da leguminosa. Brasília, DF: Embrapa, 2003, Disponível em: <http://sistemasdeproducao.cnptia.embrapa.br/FontesHTML/ Alfafa/SistemaProducaoAlfafa/>. Acesso em 21 set. 2013.

RECHCIGL, J. E. et al. Influence of surface liming on the yield and nutrient concentration of alfalfa established using no-tillage techniques. Agronomy Jounal, v. 77, p. 956-959, 1985 .

RHEINHEIMER, D. S. et al. Alterações de atributos do solo pela calagem superficial e incorporada a partir de pastagem natural. Revista Brasileira de Ciência do Solo, v. 24, p. 797805, 2000.

WERNER, J. C. et al. Recomendações de adubação e calagem para o Estado de São Paulo. Campinas, Instituto Agronômico \& Fundação IAC, 1996, p. 245-248 (Boletim técnico 100). 